\title{
Peer Review Under the Ethical Lens: Possible Questions
}

\section{Stručna recenzija pod etičkim povećalom: moguća pitanja}

\author{
Alexandru-Ionuţ Petrişor \\ Ion Mincu University of Architecture and Urbanism, Bucharest, Romania \\ alexandru.petrisor@uauim.ro (institutional), alexandru_petrisor@yahoo.com (personal)
}

Article Info / Informacije o članku

Primljen / Received 28. 2. 2020.

Prihvaćen / Accepted 9. 4. 2020.

Dostupan online / Available online: 15. 12. 2020.

Keywords / Ključne riječi

predatory publishers, article impact assessment, transparency, journal management, editorial roles, conflicts, funding

grabežljivi izdavači, procjena utjecaja/odjeka članaka, transparentnost, upravljanje časopisima, uredničke uloge, sukobi, financiranje

\begin{abstract}
Sažetak
The pressure to publish and get cited along with the extensive use of citation metrics in individual career promotion, research funding and university ranking have radically changed the research ecosystem during the last few decades, favoring the rise of predatory journals. This phenomenon has shaken the very backbone of the system, represented by the peer review process. The present article builds up upon the recommendation for reviewers, including the ethical ones, and articles expressing some concerns related to the peer review in order not to answer, but merely ask several questions that could serve as the start point for a reform of the system. Overall, the role of peer review is not at stakes, but its intricate mechanisms need to adapt to the challenges of the new environment.
\end{abstract}

Pritisak da se rad objavi i citira zajedno s velikom upotrebom citatskih metrika u individualnoj promociji karijere, financiranju istraživanja i rangiranju univerziteta radikalno su promijenili istraživački ekosistem tijekom posljednjih nekoliko desetljeća, pogodujući porastu grabežljivih časopisa. Ovaj fenomen je uzdrmao samu okosnicu sistema, predstavljenog postupkom stručne recenzije. Ovaj se članak temelji na preporuci za recenzente, uključujući etiku, te članci izražavaju zabrinutost koja se odnosi na recenziju, ne kako bi dali odgovor, već postavljajući samo nekoliko pitanja koja bi mogla poslužiti kao polazište za reformu sistema. Sveukupno, uloga stručne provjere nije na kocki, ali njeni zamršeni mehanizmi moraju se prilagoditi izazovima novog okruženja.

\section{Introduction}

From a global perspective, peer review is not new. The first journal using it to evaluate articles before their publication was "Philosophical Transactions of the Royal Society", published its first issue in 1665 (Lovejoy et al. 2011; Dizdar 2019). It would seem that 355 years were sufficient for the peer review to perfect its mechanisms sufficiently for eliminating all possible problems. Nevertheless, the recent pressure to "publish or perish" (Memon 2018), correlated with the transformation of research into a business (Corlan 2005) and consequent growth of open access publications (Beall 2013; Dizdar 2019) have resulted into the emergence and proliferation of predatory journals (Petrişor 2016; 2018). The efforts for discerning them from the legitimate journals, and experiments such as Bohannon's "trap" (2013), showing that even legitimate journals might be unable to control the scientific quality using the peer review, have risen concerns, calling for re-asking a question repeated over more than a decade at least directly by the title of an article (Mulligan

\section{Uvod}

Iz globalne perspektive, stručno recenziranje nije novina. Prvi časopis koji ga je koristio za ocjenjivanje članaka prije njihova objavljivanja bio je časopis Philosophical Transactions of the Royal Society, objavom svog prvog broja 1665. godine (Lovejoy et al. 2011; Dizdar 2019). Čini se da je 355 godina bilo dovoljno stručnom recenziranju za usavršavanje mehanizama za uklanjanje svih mogućih problema. I pored toga, nedavni pritisak "objaviti ili propasti” (Memon 2018), povezan s transformacijom istraživanja u biznis (Corlan 2005) i posljedični rast publikacija s otvorenim pristupom (Beall 2013; Dizdar 2019), rezultirali su pojavom i širenjem grabežljivih časopisa (Petrişor 2016, 2018). Napori da ih se razazna od legitimnih časopisa te eksperimenti poput Bohannonove "zamke" (2013), pokazuju da čak i legitimni časopisi možda neće moći kontrolirati naučnu kvalitetu pomoću stručnog recenziranja, što je izazvalo zabrinutost, pozivajući na ponovno postavljanje pitanja koje je ponavljano više od desetljeća, barem izravno s naslovom članka (Mulli- 
2005) or a section of an article (Baldwin 2017) and indirectly by others (Kangas and Hujala 2015), i.e., Is peer review in crisis?

Moreover, if journals and worldwide publishers with a long experience in using peer review might have only a need for fine tuning the process in order to eliminate the concerns, emerging journals, especially from countries without a tradition in peer reviewed publishing, might be puzzled, since the models that they are copying have proven their shortcomings; if the money issue comes into place, examples like "Metalurgia International" (Djuric 2015) suggest the need for a careful examination of peer reviewing, since, guarding the proportions, even legitimate journals might adopt predatory practices, such as poor quality control (Cobey et al. 2018), if running short of funding (Habibzadeh and Simundic 2017). Kim (2018) and Pomponi et al. (2019) cite examples of rejected papers that turned even into Nobel prizes, while Risness (2018) mentions examples of variable reviewer reports, resulting into rejected articles that should have been published and published manuscripts that should have been rejected.

In addition to these, the increasing number of journals (Mabe 2003), especially in the developing countries (Holmgren and Schnitzer 2004) has resulted into the recruitment of reviewers becoming harder (Fox et al. 2017). At the same time, the trends suggest that the global scientific output doubles every nine years (Bornmann and Mutz 2015). When looking at the "top reviewers", Pomponi et al. (2019) found out, according to the official statistics, that they produce reviews at a very high speed, with very little time (and probably attention) given to the process. These trends give a new course to the editor - reviewer - author nexus especially with established journals, which do not lack submissions. In the journal equation, loosing a reviewer, especially a good one, becomes less desirable than loosing an author. In simpler words, reviewers do matter (Kim 2018).

An essential question, standing as a key for understanding the article, is the very essence of peer review. While there are numerous definitions (e.g., Mulligan 2005; Björk 2018, in addition to those provided by publishers like Elsevier, Springer, Taylor \& Francis or Wiley), they all say the same as the words; peer review is the process of reviewing (or refereeing) an article by peers, i.e. scientists with expertise in the area of the article. The analysis of the definition shows that there are at least two roles: (1) "filtering" which articles are published from all gan 2005) ili dijelom članka (Baldwin 2017), a neizravno od drugih (Kangas i Hujala 2015), tj. Da li je recenziranje u krizi?

Štoviše, ako bi časopisi i svjetski izdavači $\mathrm{s}$ dugogodišnjim iskustvom u korištenju stručnog recenziranja mogli imati potrebu samo za dotjerivanjem postupka kako bi se uklonila zabrinutost, novi časopisi, posebno iz zemalja bez tradicije stručno recenziranog objavljivanja, mogu biti zbunjeni, budući da su modeli koje kopiraju dokazali svoje nedostatke; ako dođe do problema s novcem, primjeri poput "Metalurgia International" (Djuric 2015) sugerišu potrebu za pažljivim ispitivanjem stručnog recenziranja, jer bi, čuvajući razmjere, čak i legitimni časopisi mogli usvojiti grabežljivu praksu, poput loše kontrole kvalitete (Cobey et al. 2018) ako nema dovoljno sredstava (Habibzadeh i Simundic 2017). Kim (2018) i Pomponi et al. (2019) navode primjere odbijenih radova koji su se pretvorili čak i u Nobelove nagrade, dok Risness (2018) spominje primjere promjenjivih izvještaja recenzenata, što rezultira odbijenim člancima koji su trebali biti objavljeni i objavljenim rukopisima koje je trebalo odbiti.

Osim ovoga, uvećani broj časopisa (Mabe 2003), posebno u zemljama u razvoju (Holmgren i Schnitzer 2004), rezultirao je time da je angažiranje recenzenata postalo teže (Fox et al. 2017). U isto vrijeme, trendovi sugerišu da se svjetska naučna proizvodnja udvostručuje svakih devet godina (Bornmann and Mutz 2015). Kada gledamo "najbolje recenzente", Pomponi et al. (2019) su otkrili prema službenoj statistici, da proizvode recenzije veoma velikom brzinom u malo vremena (i vjerovatno pažnje) u procesu. Ovi trendovi daju novi smjer vezi urednik - recenzent - autor posebno s afirmiranim časopisima kojima ne nedostaje prijavljenih radova. U računici časopisa, gubitak recenzenta, pogotovo dobrog recenzenta, postaje manje poželjan od gubitka autora. Jednostavnijim rječnikom: recenzenti jesu važni (Kim 2018).

Ključno pitanje koje stoji kao ključ za razumijevanje članka jest sama suština stručne recenzije. Iako postoje brojne definicije (npr. Mulligan 2005; Björk 2018, uz one koje pružaju izdavači poput Elseviera, Springera, Taylora i Francisa ili Wileyja), svi govore isto: stručna recenzija je postupak pregleda (ili prosuđivanja) članka od strane kolega, tj. naučnika sa stručnošću u području članka. Analiza definicije pokazuje da postoje bar dvije uloge: (1) "filtriranje" koji su članci od svih prijavljenih objavljeni i (2) poboljšanje kvaliteta prijavljenih članaka. Dvije su 
those submitted, and (2) improving the quality of submitted articles. The two functions are somehow combined, because in most cases the peer review process includes an initial selection, and only the accepted articles are improved; those not meeting the quality standards are rejected from the very beginning, or whenever it considered that the authors did not cooperate sufficiently to increase the quality of their submissions.

Starting from this background, this article builds on the premise that during the 355 years peer review passed through three stages, used as a magnifying glass for examining the process from an ethical perspective. These stages are somehow reiterated by each emerging journal during the process of establishing its presence and findings its niche. In a nutshell, the three stages are: (1) a "technical" assessment of the quality of the articles only, (2) a "technical" assessment of the quality of the entire research process behind what can be read in the article, and (3) an assessment of the potential impact of the article. In more details, although the first steps might be joined, and for an already established journal the assessment is done at once, with the first step resulting into "minor revisions" and the second in "major" ones, for the purpose of this analysis they are seen as distinct stages of the growth of journals. The third stage is characteristic to journals that are already established, have stable editorial teams, well established mechanisms of control, and a large pool of articles for selection.

The aim of the article is to challenge some reflections on the very essence of the peer review process, looking at several examples selected from the recommendations for reviewers from several major publishers, and articles that have raised concerns about the peer review in general, or on particular shortcomings or cases.

\section{Core issues of the peer review process}

The peer review process has witnessed many attempts to improve its quality; while initially the peer review was a pre-publication step, nowadays post-publication review is also possible. The variations - including the "blindness" types, presence of several stages (initial screening and multiple review rounds) did not change the essence mentioned in the previous section. However, the essential questions are still addressing the three core words: process, review, and peer.

1. Peer review is a process. While in general peer review is a process, its variations can challenge this funkcije na neki način kombinovane, zato što u većini slučajeva postupak stručne recenzije uključuje početnu selekciju, a poboljšani su samo prihvaćeni članci; oni koji ne ispunjavaju standarde kvalitete, odbijaju se na samom početku ili bilo kada, kada se smatra da autori nisu sarađivali dovoljno da bi povećali kvalitetu svojih prijavljenih članaka.

Polazeći od ove postavke, ovaj se članak temelji na pretpostavci da je tokom 355 godina recenzija prošla kroz tri faze i korištena kao povećalo za ispitivanje procesa iz etičke perspektive.

Ove se faze ponavljaju na neki način sa svakim nastankom časopisa u procesu utvrđivanja svoje prisutnosti i pronalaska svoje biti. Ukratko, tri faze su: (1) "tehnička" ocjena kvalitete samo članaka, (2) "tehnička" procjena kvalitete cjelokupnog istraživačkog procesa iza onoga što se može pročitati u članku i (3) procjena potencijalnog utjecaja članka. Detaljnije, iako se prvi koraci mogu spojiti, a za već afirmirani časopis procjena se odmah radi, s prvim korakom koji je rezultirao "manjim izmjenama" i sa drugim, "velikim", za potrebe ove analize posmatraju se kao zasebne faze razvoja časopisa. Treća faza je karakteristična za već afirmirane časopise koji imaju postojane uredničke timove, dobro uspostavljene mehanizme kontrole i veliki broj članaka za odabir.

Cilj članka je izazvati neka razmišljanja o samoj biti postupka stručne recenzije, gledajući nekoliko izabranih primjera iz preporuka za recenzente nekoliko glavnih izdavača i članaka koji su uzrokovali zabrinutost za stručno recenziranje općenito, ili o određenim nedostacima ili slučajevima.

\section{Ključna pitanja procesa stručne recenzije}

Proces stručne recenzije svjedočio je mnoge pokušaje poboljšanja svoje kvalitete; dok je u početku stručna recenzija bila korak prije objavljivanja, sada je također moguće recenziranje poslije objave. Varijacije - uključujući "slijepe" vrste, prisutnost nekoliko faza (početna provjera i više krugova recenziranja) nisu promijenile bit spomenutu u prethodnom dijelu. Međutim, ključna pitanja se još uvijek bave trima ključnim riječima: proces, pregled i kolege.

1. Stručno recenziranje je proces. Iako je generalno stručna recenzija postupak, njene varijacije mogu osporiti ovu odliku. Na primjer, ako je članak odbijen na samom početku (pogotovo ako postoji početna provjera), "proces" je sveden na jedan korak. Očito, za časopise s visokom stopom odbijanja ovo je "obaveza" jer recenzenti rade besplatno. Ne bi 
feature. For example, if an article is rejected from the very beginning (especially if there is an initial screening), the "process" is resumed to a single step. Obviously, for journals with a high rejection rate this is a "must", since reviewers act free of charge. It would not make sense to consume the time and efforts of the reviewers to make a decision which can be easily foreseen. However, this very simple judgment has many consequences. In the age of political correctness, Springer (2019) reserves the right to edit a report in order to remove offensive language, and Wiley (2019a) recommends Editors to not use insulting, hostile, or defamatory language; obviously, the editors are doing the same. For this reason, general issues, such as the article not fitting to the aims and scope of the journal; non-compliance with the editing guidelines; incomprehensible/poor language are provided by most journals, and the lack of research depth or novelty by the top ones. For the authors at the beginning of their career or from countries unfamiliar with the process, such arguments are not helpful. Moreover, it is very likely that the rejection due to language reasons favored the predatory journals (Soler and Cooper 2019), and even their transformation of predatory publishers into proofreading services (Petrişor 2017).

At the same time, the assessment of the revised manuscript by a reviewer asks for the decision whether to consider it as a new article, assess whether the initial comments were properly and fully addressed, or a combination of the two (Lovejoy et al. 2011). The possible answer may change the object of evaluation (the article, the entire research, or their impact). Furthermore, the Academy of Management (2020) expresses a clear warning: Revised and accepted papers should always reflect the author's voice, as opposed to that of the reviewer or action editor. Similarly, Lovejoy et al. (2011) found that young reviewers tend to recommend redoing the study their way with respect to the study design and methodology. This is, by far, a major concern exploited by those who oppose the peer review system.

2. Who are the "peers"? The Committee on Publication Ethics (COPE) Council Guidelines (2019) require reviewers to have the necessary expertise to assess the manuscript and can be unbiased in their assessment. However, science has expanded so much, and new areas emerge frequently. Furthermore, there is an increasing need for interdisciplinary research. As a result, finding the perfect peers is very rare. A long time is required for the editors simply knowing the reviewers, including their decision. A relatively new initiative, Publons, imalo smisla trošiti vrijeme i napore recenzenata da donesu odluku koja se lako može predvidjeti. Međutim, ova vrlo jednostavna odluka ima mnogo posljedica. U doba političke korektnosti, Springer (2019) zadržava pravo da uredi izvještaj kako bi uklonio uvredljivi govor, a Wiley (2019a) preporučuje urednicima da ne koriste uvredljive, neprijateljske ili klevetničke riječi; očigledno i urednici rade isto. Zbog ovog su razloga osnovni problemi, npr. članak ne odgovara ciljevima i području časopisa; nepoštivanje smjernica za uređivanje; nerazumljivo/slabo znanje jezika, navedeni u većini časopisa, kao i nedostatak ozbiljnog istraživanja ili novina od strane najboljih. Za autore na početku karijere ili iz zemalja koje nisu upoznate s postupkom, takvi argumenti nisu od pomoći. Štoviše, vrlo je vjerojatno da je odbijanje zbog jezičnih razloga pogodovalo grabežljivim časopisima (Soler and Cooper 2019), pa čak i njihovoj transformaciji iz grabežljivih izdavača u lektorske servise (Petrişor 2017).

$\mathrm{U}$ isto vrijeme, procjena ispravljenog članka od strane recenzenta zahtijeva odluku da li se on sad treba smatrati novim člankom, procjenu da li su prvobitni komentari pravilno i potpuno riješeni ili su kombinacija oba (Lovejoy et al. 2011). Mogući odgovor može promijeniti predmet evaluacije (članka, cjelokupnog istraživanja ili njegovog utjecaja). Nadalje, Academy of Management (2020) izražava jasno upozorenje: Prerađeni i prihvaćeni rad treba uvijek reflektovati autorov glas za razliku od recenzentovog ili urednikovog postupka. Slično, Lovejoy et al. (2011) nalaze da mladi recenzenti imaju tendenciju preporučivati prepravljanje studije na njihov način $s$ obzirom na dizajn i metodologiju istraživanja. Ovo je daleko najveća briga koju iskorištavaju oni koji se protive sistemu stručnog recenziranja.

2. Ko su "kolege"? Smjernice Vijeća Komiteta za etiku naučnih publikacija (The Committee on Publication Ethics (COPE) Council Guidelines) (2019) zahtijeva od recenzenata da imaju potrebnu stručnost u procjeni rukopisa te da budu nepristrasni u svojim ocjenama. Međutim, nauka se toliko razvila da se često pojavljuju nova područja. Nadalje, tu je i sve veća potreba za interdisciplinarnim istraživanjima. Kao rezultat, pronalazak savršenih kolega je veoma rijedak. Dugo vremena je potrebno da urednici jednostavno upoznaju recenzente, uključujući i njihove odluke. Relativno nova inicijativa, Publonsa, sada dijela Clarivate Analyticsa, veoma je korisna za ovu svrhu. Jednostavna statistika, kao što su preporuke dane za prethodne evaulacije (odbijanje vs. prihvaćanje), prosječna dužina recenziranja, vlastite metrike istraživanja itd., mogu biti korisni 
now part of Clarivate Analytics, is extremely useful for the purpose. Simple statistics, such as the recommendations made for the previous evaluations (rejection vs. acceptance), average length of the review, own research metrics etc., can be useful tools for selecting potential reviewers. However, identifying the right person does not guarantee its willingness and availability for reviewing. On the other hand, Pomponi et al. (2019) questions the quality of reviews performed by the "top reviewers", especially when a rewarding system is used. In order to avoid the potential conflicts of interests, journals were asking authors to nominate people who could act as reviewers, and more recently, those who should not be contacted. In the first case, authors were asked to nominate people from a different country and/or institution; however, provided the existence of multi-national universities or research organizations, and the existence of international collaborative networks, none of these conditions is able, alone, to ensure that the conflicts of interest are avoided, and journals must rely on the ethics of the authors. Occasionally, fraudulent cases were identified when authors created bogus reviewers and e-mail addresses (Greene 2015).

3. What is the meaning of "reviewing"? According to the dictionary, a review is a "formal assessment of something with the intention of instituting change if necessary" (Google 2019). The definition stresses out the two purposes of the peer review, but requires a good definition of "something". While the answer seems to be obvious, i.e., a submitted article, the real nature varies, as discussed before, from assessing the article itself, the process that led to its creation (in most cases, research), and ultimately its impact.

If the article is assessed, answers to the other possible evaluations might be included; the reviewer might ask the question whether the article reflects accurately the research process, from documenting and framing correctly the research question or hypothesis to accurately describing the methods and findings, and discussing them, or questioning its impact at least up to asking whether the article can be understood by the audience of the journal where it was submitted.

When the entire research is assessed, in addition to checking if all steps are properly documented in the article, the reviewer evaluates them qualitatively. At this point, the analysis looks at anything that could challenge the validity of results, from the methodology to its application and interpretation of findings. alati za izbor potencijalnih recenzenata. Međutim, indentifikovanje prave osobe ne garantira njegovu spremnost i dostupnost za recenziranje. S druge strane, Pomponi et al. (2019) propituju kvalitet recenzija koje rade "najbolji recenzenti", pogotovo kada se koristi nagradni sistem. Kako bi se izbjegli potencijalni sukobi interesa, časopisi su pitali autore da nominiraju osobe koji bi mogli biti recenzenti, a odskora i one s kojima se ne smije kontaktirati. U prvom slučaju, autori su zamoljeni da nominiraju osobe iz različitih zemalja i/ili institucija; međutim, pod uslovom postojanja multinacionalnih univerziteta ili istraživačkih organizacija te međunarodnih mreža saradnje, niti jedan od ovih uslova sam ne može osigurati da se izbjegnu sukobi interesa, te se časopisi moraju osloniti na etičnost autora. Povremeno su slučajevi prevara identifikovani kada su autori osmislili lažne recenzente i kreirali lažne email adrese (Greene 2015).

3. Šta je smisao "recenziranja"? Prema rječniku, recenzija je formalna ocjena nečega s intencijom uvođenja promjene ako je potrebno (Google 2019). Definicija naglašava dvije svrhe naučne recenzije, ali zahtijeva dobru definiciju "nečega". Dok se odgovor čini očiglednim, tj. to je predani članak, prava priroda varira, kao što je već razmotreno, od procjene samog članka, procesa koji je doveo do njegovog stvaranja (u većini slučajeva, istraživanju) i u konačnici njegovog utjecaja.

Ako je članak ocijenjen, mogu se uključiti i odgovori na druge moguće evaluacije; recenzent može postaviti pitanje da li članak odražava tačan proces istraživanja, od ispravnog dokumentiranja i uokvirivanja istraživačkog pitanja ili hipoteze kako bi tačno opisao metode i nalaze, raspravljajući o njima ili propitivajući njegov utjecaj, pa sve do pitanja može li članak razumjeti publika časopisa u koji je poslan.

Kada se procijeni cjelokupno istraživanje, pored provjere svih koraka koji su pravilno dokumentovani u članku, recenzent ih kvalitativno ocjenjuje. U ovom trenutku, analiza gleda na sve što bi moglo dovesti u pitanje valjanost rezultata, od metodologije do njegove primjene i interpretacije nalaza. Tipičan pokazatelj ove analize u izvještaju recenzija sastoji se od traženja prepravki istraživanja kako bi se uzeli u obzir metodološki nedostatci koje su utvrdili recenzenti. Na primjer, Elsevier (2019c) pita recenzente: Mogu li ili trebaju li autori uključiti dodatne materijale? i Predložite dodatne eksperimente ili analize. Slično, Wiley (2019b) savjetuje recenzente da ukažu na to koja su predložena do- 
A typical indication of this analysis in the review reports consists of asking for redoing the research in order to account for the methodological flaws identified by reviewers. For example, Elsevier (2019c) asks the reviewers: Could or should the authors have included supplementary material?, and Suggest additional experiments or analyses. Similarly, Wiley (2019b) advises reviewers to indicate which suggested additional investigations are essential to support claims made in the manuscript under consideration and which will just strengthen or extend the work. Wiley recommendations are based on the ones from COPE Council (2019): Be clear which (if any) suggested additional investigations are essential to support claims made in the manuscript under consideration and which will just strengthen or extend the work. The main concern here is, when the journals publish funded research, how ethical is it to allow reviewers asking for redoing the entire research or parts of it, provided that the financial and times resources of the project leading to the article have already been used? It would be fair to reject the manuscript if considering that the methodological flaws were likely to invalidate the conclusions, but a revision involving redoing the experiments or adding additional ones should be regarded with more caution. As a matter of fact, COPE Council (2019) is very clear about this: It is not the job of the reviewer to extend the work beyond its current scope. However, Noble (2017) suggests a different approach, saying that for an author it is certainly acceptable to say that the requests go beyond what you perceive to be the scope of the current work, yet if the reviewer asks for 10 things, and you say that 9 out of 10 of them fall outside the scope of your work.

If the potential impact is analyzed, the reviewer is basically answering questions like: How broad is the potential audience of the article? How novel is the article, from the theoretical and/or methodological perspectives? Does the article indicate sufficient research depth? For example, Elsevier (2018) used to indicate, in the schematics of the peer review process, two reasons for the initial rejection: incorrect refs and basic science, the second expression meaning the lack of research depth.

\section{What should the reviewers be looking for?}

Different publishers have a broad range of requirements for the reviewers. Most of them direct the reviews to answering questions ranging from a simple assessment of the article only up to looking at the entire research process and eventually evaluating the potential impact. datna istraživanja esencijalna da podrže tvrdnje iznesene u rukopisu koji se razmatra i koja će samo ojačati ili proširiti rad. Wileyjeve preporuke su bazirane na preporukama COPE vijeća (2019): Budite jasni koja su (ako ijedna) predložena dodatna istraživanja esencijalna da podrže tvrdnje iznesene u rukopisu koji se razmatra i koja će samo ojačati ili proširiti rad. Ovdje je glavna briga, kada časopis objavi financirano istraživanje, koliko je etično dopustiti recenzentima da traže ponavljanje cijelog istraživanja ili njegovih dijelova, ako su financijski i vremenski resursi projekta koji su doveli članka već iskorišteni? Bilo bi pošteno odbiti rukopis uzimajući u obzir da bi metodološke pogreške mogle poništiti zaključke, dok reviziju koja uključuje ponavljanje eksperimenta ili dodavanje dodatnih treba razmotriti s više opreza. Zapravo, COPE vijeće (2019) izjasnilo se u vezi s ovim: Posao recenzenta nije proširivanje rada izvan njegovog trenutnog djelokruga. Međutim, Noble (2017) sugeriše drugačiji pristup, govoreći da je za autora: sigurno prihvatljivo reći da zahtjevi nadilaze ono što smatra opsegom trenutnog rada, ali samo ako recenzent zatraži 10 stvari, a vi kažete da njih 9 od 10 ne spada u opseg vašeg rada.

Ako je analiziran potencijalni utjecaj, recenzent $u$ osnovi odgovara na pitanje: Koliko je široka potencijalna publika članka? Koliko je članak nov iz teorijske i/ili metodološke perspektive? Pokazuje li članak dovoljnu dubinu istraživanja? Na primjer, Elsevier (2018) je pokazivao u shemama postupka stručne recenzije dva razloga za početno odbijanje: netačne reference i osnovna nauka, drugi izraz označava nedostatak dubine istraživanja.

\section{Šta bi recenzenti trebali tražiti?}

Različiti izdavači imaju širok raspon zahtjeva za recenzente. Većina njih usmjerava recenzije da odgovore na pitanja u rasponu od samo jednostavnih procjena članka do promatranja cjelokupnog procesa istraživanja i na kraju procjene potencijalnog utjecaja.

(1) Zahtjevi vezani za analizu članka prisutni su kod svih analiziranih izdavača. Elsevier (2019c) postavlja pitanja kao: Je li korištena odgovarajuća struktura [...]?, Da li je uvod efektivan, jasan i dobro organizovan?, Može li kolega ponoviti eksperimente $i$ dobiti iste rezultate? Da li su autori uključili ispravne reference za prethodno objavljenu metodologiju? Da li je opis nove metodologije tačan?, Predložite poboljšanja u načinu prikazivanja podataka, Komentarišite općenitu logiku i opravdanosti tumačenja i zaključaka, Komentarišite broj slika, 
(1) Requirements related to analyzing the article only are present with all the publishers analyzed. Elsevier (2019c) asks questions like: Has the appropriate structure [...] been used?, Is the introduction effective, clear and well organized?, Can a colleague reproduce the experiments and get the same outcomes? Did the authors include proper references to previously published methodology? Is the description of new methodology accurate?, Suggest improvements in the way data is shown, Comment on general logic and on justification of interpretations and conclusions, Comment on the number of figures, tables and schemes, Request toning down of unjustified claims and generalizations, Check accuracy, number and citation appropriateness, Comment on any footnotes, Comment on figures, their quality and readability, Assess completeness of legends, headers and axis labels, Check presentation consistency, or Comment on need for color in figures. Taylor \& Francis (2019b) tells authors what reviewers are looking for: the study design and methodology are appropriate and described so that others could replicate what you've done; you've engaged with all the relevant current scholarship; results are appropriately and clearly presented. MDPI (2019) groups the questions for reviewers in the quality of presentation: Is the article written in an appropriate way? Are the data and analyses presented appropriately? Are the highest standards for presentation of the results used?, and scientific soundness: Are the methods, tools, software, and reagents described with sufficient details to allow another researcher to reproduce the results?

(2) There are fewer specific requirements for looking the entire process. MDPI (2019) asks: Is the study correctly designed and technically sound? Are the analyses performed with the highest technical standards? Are the data robust enough to draw the conclusions? Wiley (2019a) suggests that If the work is not clear because of missing analyses, the reviewer should comment and explain what additional analyses would clarify the work submitted. Elsevier (2019c) recommends reviewers to Suggest additional experiments or analyses.

Moreover, Lovejoy et al. (2011) dedicate an important part of their discussion to the statistical analyses, showing that statistical analyses might be unfamiliar for both novice and seasoned reviewers. However, concerns can go beyond this. Are statistical analyses always needed? Petrişor (2019) asks whether the use of statistics is a real necessity or a result of the publication bias resulting from the positivist approach, concluding that the answer is tablica i shema, Zahtijevajte umanjenje neopravdanih tvrdnji i generalizacija, Provjerite tačnost, broj i prikladnost citata, Komentarisite bilo koje fusnote, Komentarišite slike, njihov kvalitet i čitljivost, Procijenite potpunost legendi, zaglavlja i oznaka osi, Provjerite dosljednost prezentacije ili Komentarisite potrebu za bojom u slikama. Taylor \& Francis (2019b) govori autorima šta recenzenti traže: dizajn studije i metodologija odgovaraju i opisane su tako da drugi mogu ponoviti što ste uradili; sudjelovali ste u svim relevantnim trenutnim stipendijama; rezultati su prikladno i jasno predstavljeni. MDPI (2019) grupira pitanja za recenzente u kvaliteti prezentacije: Da li je članak napisan na odgovarajući način? Da li su podaci i analize predstavljeni na odgovarajući način? Da li su korišteni najviši standardi za prezentaciju rezultata? i naučnu ispravnost: Da li su metode, alati, softver i reagensi opisani s dovoljno detalja da bi drugi istraživač mogao reproducirati rezultate?

(2) Ima i manje specifičnih zahtjeva za sagledavanje cijelog postupka. MDPI (2019) pita: Da li je studija pravilno dizajnirana $i$ tehnički ispravna? Izvode li se analize prema najvišim tehničkim standardima? Da li su podaci dovoljno jaki da donose zaključke? Wiley (2019a) sugeriše da Ako rad nije jasan zbog nedostajućih analiza, recenzent bi trebao komentarisati i objasniti koje bi dodatne analize razjasnile prijavljeni rad. Elsevier (2019c) preporučuje recenzentima: Predložite dodatne eksperimente ili analize.

Osim toga, Lovejoy et al. (2011) posvećuju važan dio svoje rasprave statističkoj analizi, pokazujući da statistička analiza može biti nepoznata i početnicima i iskusnim recenzentima. Međutim, zabrinutost može ići dalje od ovoga. Da li su statističke analize uvijek potrebne? Petrişor (2019) pita da li je upotreba statistike realna potreba ili rezultat pristranosti objavljivanja koja proizlazi iz pozitivističkog pristupa, zaključujući da je odgovor mješavina oba, što znači da je malo vjerojatno da će vrhunski časopisi objaviti nalaze koji nisu podržani statističkim analizama, čak i na visokim razinama statističke značajnosti, što predstavlja "pristranost objavljivanja" (Petrişor 2010). Međutim, drugi tip pristranosti objavljivanja može biti otkriven, što znači da studije koje ne koriste uobičajene statističke metode vjerojatno neće biti objavljene, iako je upotreba alternativnih metoda dobro opravdana statističkim obrazloženjem, kada recenzenti nisu upoznati sa statistikma.

(3) Svi veliki izdavači uključuju preporuke za procjenu potencijalnog utjecaja prijavljenog rada. El- 
a mixture of the two, meaning that top journals are highly unlikely to publish findings that are not supported by statistical analyses, even at high levels of statistical significance, which represents a "publication bias" (Petrişor 2010). However, a second type of publication bias might be detected, meaning that studies that do not use the mainstream statistical methods are not likely to be published, although the use of alternative methods is well justified by the statistical rationale, when reviewers are not familiar with statistics.

(3) All major publishers include recommendations for assessing the potential impact of submissions. Elsevier (2019c) includes questions like Is the research original, novel and important to the field? and Comment on importance, validity and generality of conclusions. MDPI (2019) has specific questions on the originality/novelty, significance, and overall merit; for the latest, reviewers are asked the following Does the work provide an advance towards the current knowledge? Do the authors have addressed an important long-standing question with smart experiments? Taylor \& Francis inform the author that reviewers have to assess the work using, among others, two criteria: your work is original or new and the work is of a high enough standard to be published in the journal. (Taylor \& Francis 2019b), and ask the reviewer: Do you feel that the significance and potential impact of a paper is high or low? (Taylor \& Francis 2019a). However, Kim (2018) shows that some journals have a special department for assessing the novelty of articles instead of leaving it with the reviewers.

In addition to them, there are other specific requirements. Debates exist whether reviewers should be held responsible for detecting any ethical misconduct (Glonti et al. 2019). COPE Council Guidelines (2019) suggest that reviewers should be on watch for any ethical misconduct. Adopting the COPE Guidelines, Wiley (2019b) requires the same. A similar requirement is made by MDPI (2019): If reviewers become aware of such scientific misconduct or fraud, plagiarism or any other unethical behavior related to the manuscript, they should raise these concerns with the in-house editor immediately. Elsevier (2019b) makes, on the one hand, the same recommendation for reviewers: raise your suspicions with the editor if you suspect plagiarism, fraud or have other ethical concerns, but, on the other hand, in its guide to ethics in publishing for the reviewers (Elsevier 2019a) says that it is NOT the role of the reviewer to detect ethics issues in papers. sevier (2019c) uključuje pitanja kao što su Da li je istraživanje originalno, novo $i$ važno za oblast? i Komentarišite važnost, valjanost $i$ općenitost zaključaka. MDPI (2019) ima specifično pitanje o originalnosti/novini, važnosti i ukupnoj zasluzi; za najnovije, recenzenti se mole za sljedeće: Pruža li rad napredak prema trenutnom znanju? Da li su autori obratili pažnju na važna dugogodišnja pitanja pametnim eksperimentima? Taylor \& Francis obavještavaju autora da recenzenti moraju procijeniti djelo koristeći, između ostalog, dva kriterija: vaše je djelo originalno ili novo i rad je dovoljno visokog standarda da se može objaviti u časopisu (Taylor \& Francis 2019b) i pitaju recenzenta: Smatrate li da je značaj i potencijalni utjecaj rada visok ili nizak? (Taylor \& Francis 2019a). Međutim, Kim (2018) pokazuje da neki časopisi imaju poseban odjel za procjenu novina u člancima, umjesto da ih ostave recenzentima.

Pored njih, tu su drugi specifični uslovi. Postoje rasprave da li bi recenzenti trebali biti odgovorni za otkrivanje bilo kakvog etičkog prekršaja (Glonti et al. 2019). Smjernice COPE vijeća (2019) predlažu da recenzenti trebaju biti na oprezu kod bilo kakvog kršenja etike. Usvajanjem COPE smjernica, Wiley (2019b) zahtijeva isto. Sličan uslov je napravio i MDPI (2019): Ako recenzenti postanu svjesni takvog naučnog nedoličnog ponašanja ili prevare, plagijarizma ili bilo kojeg drugog neetičkog ponašanja vezanog za rukopis, trebaju svoju zabrinutost odmah podijeliti s internim urednikom. Elsevier (2019b) pravi, s jedne strane, istu preporuku recenzentima: podijelite sumnju s urednikom ako sumnjate na plagijarizam, prevaru ili imate bilo koju drugu etičku zabrinutost, ali, s druge strane, u svom vodiču za recenzente za etiku objavljivanja (Elsevier 2019a) govori uloga recenzenta NIJE da otkriva etičke probleme u radovima.

Drugo pitanje je da li su recenzenti odgovorni da provjeravaju da li je rukopis u skladu s preporukama za autora. Taylor \& Francis (2019b) ostavlja uredniku: Da li je autor slijedio preporuke časopisa u Uputama za autore? Međutim, Lovejoy et al. (2011) predlažu da recenzenti trebaju također gledati stilske greške publikacije i dati komentare poput Reference ne slijede preporuke stila časopisa. Slično, da li su recenzenti odgovorni za lektorisanje i provjeru pravopisa? Odgovori su kontradiktorni (Glonti et al. 2019). Taylor \& Francis (2019a) imaju lijepo podešen odgovor: Posao recenzenta nije da uređuje rad na engleskom, ali je korisno da se engleski ispravi gdje je tehničko značenje nejasno. 
Another question is whether the reviewers are responsible to check whether the manuscript complies with the author guidelines. Taylor \& Francis (2019b) leave it with the Editor: Has the author followed the journal's guidelines in the Instructions for Authors? However, Lovejoy et al. (2011) suggest that reviewers should also look at publication style errors and make comments like References do not follow journal style guidelines.

Similarly, are reviewers responsible for copy-editing and spell checking? The answers are contradictory (Glonti et al. 2019). Taylor \& Francis (2019a) have a fine tuned answer: It's not the reviewer's job to edit the paper for English, but it is helpful if you correct the English where the technical meaning is unclear. [...] Is the submission in Standard English to aid the understanding of the reader? However, MDPI (2019) holds reviewers responsible for assessing the level of English, and assess whether it is appropriate and understandable. Elsevier (2019c) asks reviewers to answer questions like: Has the appropriate [...] language been used? and List separately suggested changes in style, grammar and other small changes. COPE Council (2019) states that suggestions for changes that improve clarity are, however, important. Lovejoy et al. (2011) believe that spelling and grammar errors should not be the reviewers' primary concern [...] Reviewers should always focus the review on the big picture.

The final resolution of the reviewer must be seen in the context of the big picture, where the decision belongs to the editor (Kim 2018), or the reviewer recommends, the editor decides (Elsevier 2019a). However, the process is not as easy as it seems. Each part might overtake its role; editors might decide against the recommendations of the reviewers, or might rely too much on them. According to Elsevier (2019b), the editor will weigh all views of the reviewers in order to take a decision. On the other hand, there are reviewers who take the editor's role and conflicts may appear especially when articles are published against their recommendation for a rejection. This issue must now be weighted cautiously, because predatory journals were proven to have published articles rejected by other journals (Björk, 2018), even despite the recommendations of reviewers (Shaghaei et al. 2018). The latest generated Publons, a platform that allowed reviewers to see what happened to their reviewing work. Such decisions might compromise the perceived quality of the journal. When authors get into the equation, the situation complicates even more, because of their right to a rebuttal letter, explaining why certain
[...] Da li je poslani rad na standardnom engleskom jeziku da pomogne u razumijevanju čitatelju? Međutim, MDPI (2019) drži recenzente odgovornim za procjenu nivoa engleskog jezika i procjenu da li je prikladno i razumljivo. Elsevier (2019c) traži od recenzenata da odgovore na pitanja poput: Da li je prikladni [...] jezik korišten? i Navedite odvojeno predložene promjene u stilu, gramatici ili neke druge male promjene. COPE vijeće (2019) navodi da su prijedlozi za promjene koje poboljšavaju jasnoću ipak važni. Lovejoy et al. (2011) vjeruje da pravopis i gramatičke greške ne trebaju biti recenzentova primarna briga [...] Recenzenti uvijek trebaju fokusirati recenziju na širu sliku.

Posljednja recenzentova odluka mora se promatrati u kontekstu šire slike, gdje odluka pripada uredniku (Kim 2018), ili recenzent preporučuje, urednik odlučuje (Elsevier 2019a). Međutim, proces nije jednostavan kao što se čini. Svaki dio može preuzeti svoju ulogu; urednici mogu odlučiti protiv preporuka recenzenata, ili se mogu previše osloniti na njih. Prema Elsevieru (2019b), urednik će izvagati sva gledišta recenzenata kako bi donio odluku. S druge strane, postoje recenzenti koji preuzimaju ulogu urednika i sukobi se mogu pojaviti posebno kada se članci objave nakon njihove preporuke za odbijanje. Ovaj se problem mora oprezno izvagati, zato što je dokazano da grabežljivi časopisi objavljuju članke koje su odbili ostali časopisi (Björk, 2018) i pored preporuka recenzenata (Shaghaei et al. 2018). Ovo je dovelo do stvaranja Publonsa, platforme koja dopušta recenzentima da vide šta se desilo s njihovim recenziranim radovima. Takve odluke mogu ugroziti percipiranu kvalitetu časopisa. Kada se autori uključe u računicu, situacija se još više usložnjava zbog njihovog prava na pismeni odgovor, objašnjavajući zašto se nisu rješavali recenzentovi komentari. Urednici trebaju dosta razboritosti kako bi bili u mogućnosti da odluče da li autori ne sarađuju i žele li da se bore protiv recenzenata ili da li recenzenti zaista traže previše.

Kako problem treba razborit pristup, mali broj izdavača ima jasne preporuke za recenzente. Ipak, ako se recenzenti upute da formulišu svoje odluke, njihova uloga je suvišna pošto njihove odluke moraju pratiti određene obrasce. Za početnu procjenu MDPI (2019) preporučuje odbijanje ako članak ima ozbiljne mane, nema originalni doprinos. Wiley (2019a) i COPE vijeće (2019) samo savjetuju recenzente da preporuke trebaju biti u skladu s komentarima danim u recenziji $\mathrm{i}$ da preporuke za urednike odgovaraju izvještaju za autore. Slično, Elsevier (2019b) savjetuje recenzente: Ako prepo- 
comments from the reviewers were not addressed. The editors need a lot of discernment in order to be able to decide whether the authors are not cooperating and prefer a combat against the reviewers, or the reviewers are actually demanding too much.

Since the issue needs a prudent approach, very few publishers have clear-cut recommendations for reviewers. After all, if reviewers would be instructed on phrasing their decision, their role is obsolete, since the decision must follow a certain pattern. For the initial assessment, MDPI (2019) recommends the rejection if the article has serious flaws, makes no original contribution. Wiley (2019a) and COPE Council (2019) only advise the reviewers that the recommendation should be congruent with the comments provided in the review and the recommendations for the editor are consistent with your report for the authors. Similarly, Elsevier (2019b) advises the reviewers: If you are recommending a revision, you must furnish the author with a clear, sound explanation of why this is necessary, and, in case of a rejection, explain your reasoning in your report. Taylor \& Francis (2019b) provide 10 reasons for rejection: non-compliance with the aims and scope of the journal; not a true article; inappropriate length; non-compliance with the author guidelines and/or scientific writing conventions; poor style, grammar, punctuation or English; lack of novelty; improper contextualization; poor theoretical framework; poor presentation; and a libelous or unethical manuscript. In addition, rejection is recommended if the revisions are too fundamental for the submission to continue being considered in its current form. Lovejoy et al. (2011) advise the reviewers not to recommend a revision if recommend a revision if, even with changes, the manuscript will not make a significant contribution. Last but not least, Annesley (2012) suggests that a reviewer might wrongly feel that recommending the rejection of a manuscript will prevent the need for assessing a revised version of the manuscript. When assessing the revised manuscript, most publishers agree on a rejection if the author failed to address properly the comments of the reviewers.

Moreover, sometimes the editors might adopt a back standing attitude and place the burden to the author, especially when contradictory review reports are received. In this case, an additional discussion is needed on an assumption related to the peer review process. There are many discussions on the advantages and disadvantages of "blindness" (Tomkins et al. 2017), but very few on the independence of reviewers evaluating the same article. The Univer- ručujete ispravke, morate dostaviti autorima jasno, zvučno objašnjenje zašto je to potrebno i, u slučaju odbijenice, objasnite razloge u svom izvještaju. Taylor \& Francis (2019b) nude 10 razloga za odbijanje: neispunjavanje ciljeva i djelokruga časopisa; nije članak, neprikladna dužina; nepridržavanje preporuka za autore i/ili konvencije naučnog pisanja; loš stil; gramatika, interpunkcija ili engleski; nedostatak noviteta; nepravilna kontekstualizacija; loš teorijski okvir; loša prezentacija; pogrdan ili neetičan rukopis. Osim toga, odbijanje je preporučeno ako su prepravke previše temeljne da bi se predani rad i dalje mogao razmatrati u njegovom sadašnjem obliku. Lovejoy et al. (2011) savjetuju recenzente da ne preporučuju prepravke ako čak $i$ s promjenama rukopis neće dati važan doprinos. Posljednje, ali ne najmanje važno, Annesley (2012) sugeriše da recenzent može pogrešno smatrati da će se preporučivanjem odbacivanja rukopisa spriječiti potreba za ocjenom revidirane verzije rukopisa. U procjeni revidiranog rukopisa, većina izdavača je saglasna s odbijenicom ako autori ne riješe recenzentove komentare.

Štoviše, urednici ponekad usvoje zaostali stav i stave teret na autora, pogotovo kada se dobiju kontradiktorni izvještaji recenzenata. U ovom slučaju, potrebna je dodatna diskusija o pretpostavkama vezanim uz postupak stručne recenzije. Postoji mnogo diskusija o prednostima i nedostatcima "slijepih recenzija" (Tomkins et al. 2017), ali malo o nezavisnosti recenzenata koji ocjenjuju isti članak. Universitet u Melbournu (2020) pretpostavlja da je recenziranje neovisno. Međutim, najgori ishod je proizvod kada recenzent djeluje neovisno u neslaganju te urednik ne zauzme stav, prosljeđujući autoru teret rješavanja oprečnih zahtjeva. Očigledno, ovo ne znači zagovaranje da recenzenti budu svjesni svega onoga šta drugi govori od samog početka, već poziva na odgovor da li teret rješavanja oprečnih opaski treba biti ostavljen autoru ili ne i da li autoru treba biti data mogućnost da prikažu oprečne opaske, izražavajući svoj izbor jedne ili druge strane, ili pak drugačije solucije. Ova prilika nije data ili se barem njena važnost umanjuje kada autori moraju napisati odvojene odgovore svakom recenzentu.

\section{Umjesto zaključka: nekoliko etičkih pitanja}

Članakjepokušao analiziratiproces stručnerecenzije s etičkog stajališta koristeći preporuke za recenzente nekoliko glavnih izdavača i literature. Analiza je otkrila ne samo različite preporuke koje postoje između različitih izdavača već i kontradiktornosti 
sity of Melbourne (2020) assumes that peer review is independent. However, the worst outcome is produced when reviewers acting independently are in disagreement and the editor does not take position, passing to the authors the burden of dealing with conflicting requirements. Obviously, this does not mean advocating for reviewers being aware each one of what the other one is saying from the very beginning, but calls for an answer to whether the burden of addressing conflicting remarks should be left to the author or not, and whether authors should be given the opportunity to display the conflicting remarks, expressing their choice for one side or the other, or for a different solution. This opportunity is not given or at least its importance is diminished when authors must write separate answers to each reviewer.

\section{Instead of conclusions: several ethical questions}

This article has attempted to analyze the peer review process from an ethical standpoint using the recommendations for reviewers of several main publishers and the literature. The analysis revealed differences which are present not only between different publishers, but also contradictions of different recommendations made by the same publisher. The need for peer review cannot be denied (Kim 2018). As Beninger et al. (2016) put it, out accepting senseless articles for publication and rejecting good manuscripts, only the first allows science to progress. Nevertheless, it is possible that, in an attempt to remove any constraints or suggestions that could influence the reviewers in their judgment, the guidelines are very general. It is also possible that, provided that these publishers manage a large number of journals from different fields, which determine a variety of characteristics, the fine tuning of policies is passed to the responsibility of the journal. Regardless of the rationale beyond it, the quest ended with a set of questions that did not find a definite answer, and are left open:

(1) Which of the two functions of the peer review is more important, filtering content or improving it? How is the answer influenced by the transformation of science into a business, provided that the reviewers are not paid for their work? And is nowadays peer review still a process? Does the final product reflect the author's or the reviewer's (or editor's) voice?

(2) Are always reviews made by the appropriate people? What qualifies a reviewer as "good" or "bad"? Are the rewarding systems influencing the quality of reviews, and even the final recommendations of the reviewers? različitih preporuka istog izdavača. Potreba stručne recenzije se ne može zanijekati (Kim 2018). Kao što Beninger et al. (2016) kažu, između prihvatanja besmislenih članaka za objavljivanje i odbijanja dobrih rukopisa, samo ovo prvo dopušta nauci da napreduje. Pa ipak, moguće je da, u pokušaju da se odstrane bilo kakva ograničenja ili sugestije koji mogu uticati na sud recenzenata, smjernice budu vrlo uopćene. Također je moguće da je, pod uslovom da ti izdavači vode veliki broj časopisa iz različitih područja koje određuju različite karakteristike, dotjerivanje politika prebačeno na odgovornost časopisa. Bez obzira na obrazloženje izvan toga, potraga je završila nizom pitanja koja nisu pronašla definitivan odgovor i ostala su otvorena:

(1) Koja je od dvije funkcije stručne recenzije važnija, filtriranje sadržaja ili njegovo poboljšavanje? Kako se na odgovor utiče transformacijom nauke u biznis, pod uslovom da recenzenti nisu plaćeni za svoj rad? I da li je danas stručna recenzija još uvijek proces? Da li finalni proizvod reflektira autorov ili recenzentov (ili urednikov) glas?

(2) Da li recenzije uvijek daju prikladne osobe? Šta kvalifikuje recenzenta kao "dobrog" ili "lošeg"? Da li sistemi nagrađivanja utiču na kvalitet recenzija i čak na finalne preporuke recenzenata?

(3) Do koje je mjere legitimno da stručni recenzenti gledaju dalje od rukopisa i traže promjene istraživačke metodologije, dodatne eksperimente ili ocjene potencijalnog utjecaja članka? Da li su stvarno potrebni ili čine ishod nadmetanja bolje metrike među časopisima?

(4) Šta u stvari recenzenti trebaju tražiti? Mogu li se recenzenti pretvoriti u policajce, tj. biti odgovorni za detektiranje akademskog nedoličnog ponašanja, ili u uredničke asistente, postavljajući ih da prepravljaju engleski ili da provjeravaju da li su se pravilno i dosljedno pridržavali preporuka autorima?

(5) Da li bi trebao postojati minimalni set preporuka koji bi pomagao recenzentima da urade svoj posao i daju najbolju odluku prema svome znanju? Šta je potencijalni uticaj "savjeta" na izvještaj recenzije i preporuka?

(6) Ko treba djelovati u slučaju sukoba između izvještaja recenzenta i recenzenata (ili određenog recenzenta) i autora? Kada, koliko često i do kojeg stepena je legitimno da urednik intervenira favoriziranjem jedne ili druge strane? 
(3) To what extent is it legitimate for the peer reviewers to look beyond the manuscript and request changes of the research methodology, additional experiments, or assess the potential impact of the article? Are these really needed, or they constitute an outcome of the competition for better metrics between the journals?

(4) What should reviewers actually be looking for? Can reviewers be turned into policemen, holding them responsible for detecting academic misconduct, or into editorial assistants, charging them with brushing up the English or checking whether the author guidelines have been properly and consistently observed?

(5) Should there be a set of minimum criteria helping the reviewers do their job and recommend the best decision to their knowledge? What are the potential influence of "hints" on the review reports and recommendations?

(6) Who should act in case of a conflict between the reviewer reports, and between the reviewers (or a certain reviewer) and the author? When, how often, and to what extent is it legitimate for the editor to intervene favoring one side or the other?

(7) Should the reviewers act independently of each other all over the duration of the peer review process? Would it help to allow for conflicting remarks be displayed after the first review stage, in order to reveal the contradictions? Should the editor settle down such contradictions, or pass the burden to the authors?

(8) Did the very essence of peer review change during the centuries of being used, or only the details? Is there a need for a reform of the peer review in an environment of predation (Linacre et al. 2019)? Does peer review need fundamental changes, or only some fine tuning? Which of the above needs more attention in this context? The same questions need to be asked in relationship to the transformation of science into a business, putting money into equation.
(7) Da li recenzenti trebaju djelovati nezavisno jedni od drugih u toku procesa stručnog recenziranja? Da li bi pomoglo da se dozvoli da se oprečne opaske prikažu nakon prve faze recenzije kako bi se otkrile kontradiktornosti? Da li bi urednik trebao riješiti takve kontradiktornosti ili ih proslijediti autorima na teret?

(8) Da li se sama suština stručne recenzije promijenila tokom stoljetne upotrebe, ili samo deta1ji? Da li postoji potreba da se reformira stručno recenziranje $u$ okružju grabežljivosti (Linacre et al. 2019)? Da li stručno recenziranje treba fundamentalne promjene ili samo dotjerivanje? Čemu od navedenog u ovom kontekstu treba posvetiti više pažnje? Isto se pitanje treba postaviti u vezi s transformacijom nauke u biznis, stavljajući novac u računicu. 


\section{Bibliography / Bibliografija}

- Academy of Management. 2020. "AMD Reviewer Resources". Last modification: 3 . January. https://aom.org/Publications/AMD/ AMD-Reviewer-Resources.aspx

- Annesley, Thomas M. 2012. "Seven Reasons Not to Be a Peer Reviewer - And Why These Reasons Are Wrong" Clinical Chemistry 58 (4): 677-679. DOI: http://doi.org/10.1373/ clinchem.2012.182618

- Baldwin, Melinda. 2017. "In referees we trust?" Physics Today 70 (2): 44-49. DOI: http://doi. org/10.1063/PT.3.3463

- Beall, Jeffrey. 2013. "Predatory publishing is just one of the consequences of gold open access" Learned Publishing 26: 79-84. DOI: http://doi.org/10.1087/20130203

- Beninger, Petter G., Jeffrey Beall, and Sandra E. Shumway. 2016. "Debasing the currency of science: the growing menace of predatory open access journals" Journal of Shellfish Research 35 (1): 1-5. DOI: http://doi. org/10.2983/035.035.0101

- Björk, Bo-Christer. 2018. "Acceptance rates of scholarly peer-reviewed journals: a literature survey" El profesional de la información 28 (4): e280407. https://doi.org/10.3145/epi.2019. jul.07

- Bornmann, Lutz, and Rüdiger Mutz. 2015. "Growth rates of modern science: A bibliometric analysis based on the number of publications and cited references" Journal of the Association for Information Science and Technology 66 (11): 2215-2222. DOI: http://doi.org/10.1002/ asi. 23329

- Cobey, Kelly D., Manoj M. Lalu, Becky Skidmore, Nadera Ahmadzai, Agnes Grudniewicz, and David Moher. 2018. "What is a predatory journal? A scoping review" F1000Research 7: 1001. DOI: http://doi.org/10.12688/f1000research.15256.2

- Committee on Publication Ethics (COPE) Council. 2019. "COPE Ethical Guidelines for Peer Reviewers". Last modification: 28. December. http://www.publicationethics.org/ Ethical_Guidelines_For_Peer_Reviewers_2. pdf

- Corlan, Alexandru D. 2005. "Scientific research is not a commercial activity [in Romanian]" $A d$ Astra 4: 1-10. http://www.ad-astra.ro/journal/7/ corlan.pdf
- Dizdar, Srebren. 2019. "Za i protiv otvorenog pristupa akademskim djelima u kontekstu savremenog istraživačko-izdavačkog procesa" Bosniaca 24: 26-38. DOI: http://doi.org/10.37083/ bosn.2019.24.26

- Djuric, Dragan. 2015. "Penetrating the omerta of predatory publishing: the Romanian connection" Science and Engineering Ethics 21 (1): 183-202. DOI: http://doi.org/10.1007/ s11948-014-9521-4

- Elsevier. 2018. "What is peer review? The peer review process: schematics". Last modification: 7. January. https://www.elsevier.com/_data/ assets/image/0007/90079/Rev_process.png

- Elsevier. 2019a. "A reviewer's guide to ethics in publishing". Last modification: 28. December. https://www.elsevier.com/reviewers-update/ story/publishing-ethics/a-reviewers-guide-topublishing-ethics

- Elsevier. 2019b. "How to conduct a review. Checklist". Last modification: 28. December. https://www.elsevier.com/reviewers/how-toreview/checklist

- Elsevier. 2019c. "How to review manuscripts. Peer review, your role and responsibilities". Last modification: 28. December 28. https:// www.publishingcampus.elsevier.com/websites/ elsevier_publishingcampus/files/Guides/ Quick_guide_how_to_review.pdf

- Fox, Charles W., Arianne Y. K. Albert, and Timothy H. Vines. 2017. "Recruitment of reviewers is becoming harder at some journals: a test of the influence of reviewer fatigue at six journals in ecology and evolution" Research Integrity and Peer Review 2: 3. DOI: http://doi. org/10.1186/s41073-017-0027-x

- Google. 2019. "Dictionary". Last modification: 28. December. https://www.google.com/ search?q=Dictionary

- Glonti, Ketevan, Daniel Cauchi, Erik Cobo, Isabelle Boutron, David Moher, and Darko Hren. 2019. "A scoping review on the roles and tasks of peer reviewers in the manuscript review process in biomedical journals" $B M C$ Medicine 17: 118 DOI: http://doi.org/10.1186/ s12916-019-1347-0

- Greene, Jan. 2015. "Fraudsters Strike Peer Review" Annals of Emergency Medicine 65 (4): A13-A15. DOI: http://doi.org/10.1016/j. annemergmed.2015.02.017

- Habibzadeh, Farrokh, and Ana-Maria Simundic. 2017. "Predatory journals and their effects on 
scientific research community" Biochemia Medica 27 (2): 270-272. DOI: http://doi.org/ 10.11613/BM.2017.028

- Holmgren, Milena, and Stefan A. Schnitzer. 2004. "Science on the Rise in Developing Countries" PLoS Biology 2 (1): 10-14. DOI: http://doi.org/10.1371/journal.pbio.0020001

- Kangas, Annika, and Teppo Hujala. 2015. "Challenges in publishing: producing, assuring and communicating quality" Silva Fennica 49 (4): 1304. DOI: http://doi.org/ 10.14214/sf.1304

- Kim, Seong-Gon. 2018. "Reviewers do matter" Maxillofacial Plastic and Reconstructive Surgery 40 (1): 1. DOI: http://doi.org/10.1186/ s40902-018-0140-x

- Linacre, Simon, Michael Bisaccio, and Lacey Earle. 2019. "Publishing in an Environment of Predation: The Many Things You Really Wanted to Know, but Did Not Know How to Ask" Journal of Business-to-Business Marketing 26 (2): 217-228. DOI: http://doi.org/10.1080/1051 712X.2019.1603423

- Lovejoy, Travis I., Tracey A. Revenson, and Christopher R. France. 2011. "Reviewing Manuscripts for Peer-Review Journals: A Primer for Novice and Seasoned Reviewers" Annals of Behavioral Medicine 42: 1-3. DOI: http://doi.org/10.1007/s12160-011-9269-x

- Mabe, Michael. 2003. "The growth and number of journals" Serials 16 (2): 191-197. DOI: http://doi.org/10.1629/16191

- MDPI. 2019. "About. For reviewers". Last modification: 28. December. https://www.mdpi. com/reviewers

- Memon, Aamir Raoof. 2018. "How to respond to and what to do for papers published in predatory journals?" Science Editing 5 (2): 146-149. DOI: http://doi.org/10.6087/kcse.140

- Mulligan, Adrian. 2005. "Is peer review in crisis?" OralOncology 41:135-141.DOI: http:// doi.org/10.1016/j.oraloncology.2004.11.001

- Petrişor, Alexandru-Ionuţ. 2010. "Ethical Issues in Epidemiological Data Analysis" Romanian Journal of Bioethics 8 (1): 101-109. https://www.researchgate.net/ publication/298166641_ETHICAL_ ISSUES_IN_EPIDEMIOLOGICAL_DATA_ ANALYSIS

- Petrişor, Alexandru-Ionuţ. 2016. "Evolving strategies of the predatory journals" Malaysian Journal of Library and Information Science 21 (1): 1-17. DOI: http://doi.org/10.22452/mjlis. vol21no1.1
- Petrişor, Alexandru-Ionuţ. 2017. "Are the predatory publishers collapsing or re-inventing themselves?" Library and Information Science Research Electronic Journal 27 (2): 71-79. https://www.libres-ejournal.info/2570/

- Petrişor, Alexandru-Ionuţ. 2018. "Predatory Publishers using Spamming Strategies for Call for Papers and Review Requests: A Case Study" DESIDOC Journal of Library \& Information Technology 38 (3): 199-207. DOI: http://doi. org/10.14429/djlit.38.3.12551

- Petrişor, Alexandru-Ionuţ. 2019. "The use and misuse of statistics in research: theory and practice" Romanian Statistical Review 67 (2): 59-70. http://www.revistadestatistica.ro/wpcontent/uploads/2019/06/RRS-2_2019_A4.pdf

- Pomponi, Francesco, Bernardino D’Amico, and Tom Rye. 2019. "Who Is (Likely) PeerReviewing Your Papers? A Partial Insight into the World's Top Reviewers" Publications 7 (15): 7010015. DOI: http://doi.org/10.3390/ publications 7010015

- Shaghaei, Najmeh, Charlotte Wien, Jakob Povl. Holck, Anita L. Thiesen, Ole Ellegaard, Evgenios Vlachos, and Thea Marie Drachen. 2018. "Being a Deliberate Prey of a Predator - Researchers' Thoughts after having Published in a Predatory Journal" Liber Quarterly 28 (1): 1-17. DOI: http://doi.org/http://doi. org/10.18352/lq. 1025

- Soler, Josep, and Andrew Cooper. 2019. "Unexpected Emails to Submit Your Work: Spam or Legitimate Offers? The Implications for Novice English L2 Writers" Publications 7: 7. DOI: http://doi.org/10.3390/ publications 7010007

- Springer. 2019. "Reviewer Guidelines". Last modification: 28. December. https://www. springer.com/authors/manuscript+guidelines?SGWID=0-40162-6-849421-0

- Taylor \& Francis. 2019a. "A guide to becoming a peer reviewer". Last modification: 28. December. https://editorresources. taylorandfrancis.com/reviewer-guidelines/

- Taylor \& Francis. 2019b. "Understanding peer review. A guide for authors". Last modification: 28. December. https://authorservices. taylorandfrancis.com/ethical-guidelines-forpeer-reviewers/

- Tomkins, Andrew, Min Zhang, and William D. Heavlin. 2017. "Reviewer bias in singleversus double-blind peer review" Proceedings of the National Academy of Sciences 114 (48): 
12708-12713. DOI: http://doi.org/10.1073/ pnas. 1707323114

- University of Melbourne. 2020. "Peer review: Good practice in peer review". Last modification: 8. January. https://staff.unimelb. edu.au/research/ethics-integrity/researchintegrity/research-integrity-in-practice/peerreview

- Wiley. 2019a. "Best Practice Guidelines on Publishing Ethics. A Publisher's Perspective. Second Edition". Last modification: 28. December. https://authorservices.wiley. com/asset/Publishing-Ethics-Best-PracticeGuidelines-Wiley.pdf
- Wiley. 2019b. "Journal reviewers". Last modification: 28. December. https:// authorservices.wiley.com/Reviewers/journalreviewers/index.html 